\title{
Hundreds of Californian species sliding towards extinction
}

\section{San Francisco}

Two hundred and twenty animal species and 600 plant species in California are "sliding toward extinction", according to the first comprehensive assessment of the state's species and natural communities, recently released by the California Nature Conservancy. The report, requested by the state legislature for use in evaluating and designing conservation legislation, found that shrinking habitats are the main threat to endangered species, which include 10 per cent of the state's native mammals, 17 per cent of native reptiles and amphibians and 27 per cent of freshwater fish. The report proposes new legislation, including tax incentives and habitat protection, to halt the decline.

California is in a unique position, according to Steve McCormick, director of the California Nature Conservancy. The state not only has more species diversity than any other area of the country because of its size and range of topography and climates, but culturally, economically and politically it is in a position to "take the wise path" towards saving its wildlife.

The report criticizes California laws that do not protect endangered species from being killed on private land, and

\section{NSF's technology fans}

Washington

Plans by the National Science Foundation (NSF) to establish centres for the exploitation of science and technology (Nature 328, 5; 1987) have drawn an enthusiastic response. Nearly 900 'letters of intent' have been sent to the NSF, mostly by individual universities but in some cases by consortia of universities, industries, national laboratories and state governments. Alan Leshner, in charge of NSF's programme for the science and technology centres, says that the variety of proposals and proposers betokens an "interesting and exciting" approach to the problems the research community faces in times of reduced funds and worries about foreign superiority.

To support all the proposed centres, NSF would need $\$ 10,000$ million over five years. So far, NSF's request for $\$ 30 \mathrm{mil}$ lion in the first year lies, with all other federal money, in budgetary limbo while Congress and the president try to agree on reducing the deficit reduction. But this programme is likely to get sympathetic attention. In the meantime, Leshner says that NSF will go ahead with evaluation and review, reducing the 875 applications to a shortlist of perhaps 40 in anticipation of financial support.

David Lindley state agencies that, without adequate funding, are not able fully to evaluate species or to review development projects.

Among its recommendations, the report proposes acceleration of state programmes to identify and acquire endangered habitats for protection, extension of the protection of endangered species onto private land and new laws to protect endangered species and their habitats.

The report also suggests tax-incentives to encourage landowners to return their land to the wild state. McCormick says these would work well for wetlands, important habitats for elk, deer and wintering water birds, which are easily restored by dismantling dams and levee systems.

California wetlands have shrunk to 4 per cent of their original extent, due to conversion to farmland, diversion of water and pollution by agricultural runoff. In 1983, the California legislature vowed to restore wetlands to 150 per cent of their present area by the year 2000 .

No attempt has been made to estimate the cost to the state of implementing the report's recommendations, and there is no indication whether any of the recommendations will be pursued by the legislature.

Marcia Barinaga

\section{Britain's space plea}

\section{London}

Mr Jack Lemming, the new director of the British National Space Centre, has supported the British government's refusal to join the expanded European space programme. His predecessor, Roy Gibson, resigned earlier this year.

Lemming said last week that, although Britain rejected outright participation in the space aircraft Hermes, it could still participate in a range of projects on which "we have not got a clear policy". He called on industry to offer support to the space industry and to boost Britain's stake in the European programme.

Reaction from industry may be mixed. Contracts worth at least $£ 2$ million have already been lost by British companies following the decision and they have also been told that they cannot bid for future work on Hermes, worth hundreds of millions of pounds. Under European Space Agency rules an industry is not eligible to work on projects which the home government refuses to support.

Lemming, a career civil servant, is due to retire at the end of this year. He nevertheless hopes to complete the campaign to involve industry and the scientific community before then. Sarah Hargreaves \section{Soviets ponder} AIDS vaccine

\section{London}

THE Soviet Union has recently stepped up research to find an anti-AIDS vaccine or prophylactic, according to Academician V.I. Pokrovskii, president of the Soviet Academy of Medical Sciences. Speaking last week at a televised news conference, he warned that the HIV-1 virus is now "at large" in the Soviet population, and has now reached people who have had no direct contact with foreigners.

Pokrovskii spoke of "around 32-33" Soviet citizens infected with HIV (human immunodeficiency virus), including one case of fully developed AIDS, plus an unspecified number of foreign students. "The first investigations" for HIV-2 have now started, Pokrovskii said.

Glasnost came late to AIDS, perhaps as a result of pre-Gorbachev propaganda which labelled it a disease of capitalism and/or the result of a bacteriological warfare experiment in the United States that went wrong. Testing Soviet citizens has considerable logistic difficulties as prostitution and homosexuality are illegal.

Voluntary anonymous testing facilities for HIV have been available for some time, but a recent decree on mandatory testing of suspected carriers and the heavy legal penalties it imposes on carriers who knowingly place others at risk make it difficult for many people in the high-risk category to trust fully in the promised confidentiality. Moreover, if the Soviet Union continues its policy of compulsory testing, it could encounter difficulties internationally. As Pokrovskii stressed, international cooperation is all-important in AIDS research. But the Hungarians who had also passed a new law on the mandatory testing of high-risk groups, now say that they may have to abandon it in the light of the agreement rejecting compulsory screening adopted by a recent conference in Paris.

In the meantime, research efforts continue, and receive considerable publicity. The popular science journal Nauka $i$ Zhizn recently described the development of 'nuclear filters' at the Dubna Joint Nuclear Research Institute. These filters, it was explained, are produced by directing a beam of charged particles at a polymer film, and can be tailored to trap the HIV virus, which would interact with the material of traditional member filters. Two weeks ago, the official news agency TASS reported that a joint research project had been agreed between Finnish scientists who have produced individual parts of an HIV-protein using genetic engineering and a Soviet team who had synthesized immunity stimulators to produce a vaccine against HIV. Vera Rich 